NBER WORKING PAPER SERIES

\title{
THE EFFECT OF BEVERAGE TAXES ON YOUTH CONSUMPTION AND BMI: EVIDENCE FROM MAURITIUS
}

\author{
John Cawley \\ Michael R. Daly \\ Rebecca Thornton \\ Working Paper 28960 \\ http://www.nber.org/papers/w28960 \\ NATIONAL BUREAU OF ECONOMIC RESEARCH \\ 1050 Massachusetts Avenue \\ Cambridge, MA 02138 \\ June 2021
}

We thank David Frisvold, Anna Hill, David Jones, Chelsea Lensing, Anne Marie Thow, Katherine Wen, and Barton Willage for detailed discussions of SSB taxes that informed this paper. The authors have no conflicts of interest to disclose. The views expressed herein are those of the authors and do not necessarily reflect the views of the National Bureau of Economic Research.

NBER working papers are circulated for discussion and comment purposes. They have not been peer-reviewed or been subject to the review by the NBER Board of Directors that accompanies official NBER publications.

(C) 2021 by John Cawley, Michael R. Daly, and Rebecca Thornton. All rights reserved. Short sections of text, not to exceed two paragraphs, may be quoted without explicit permission provided that full credit, including $(\odot)$ notice, is given to the source. 
The Effect of Beverage Taxes on Youth Consumption and BMI: Evidence from Mauritius John Cawley, Michael R. Daly, and Rebecca Thornton

NBER Working Paper No. 28960

June 2021

JEL No. H2,H3,I12,I18,L66,O1

\begin{abstract}
$\underline{\text { ABSTRACT }}$
Taxes on sugar-sweetened beverages (SSBs) are relatively new and there is little evidence about their impact on SSB consumption or body mass index (as opposed to prices, purchases, or sales), their impact on youth (as opposed to on adults), or their impact in non-Western nations. This paper adds to the evidence base on all of these dimensions by estimating the effect of an SSB tax on the consumption and BMI of youth in Mauritius, an island nation in the Indian Ocean, which we compare to Maldives, another island nation in the Indian Ocean which did not implement an SSB tax during the time of our data. Results of difference-in-differences models indicate that the tax in Mauritius had no detectable impact on the consumption of SSBs or the body mass index of the pooled sample of boys and girls. However, models estimated separately by sex indicate that the probability that boys consumed SSBs fell by 9.4 percentage points $(11 \%)$. These are among the first estimates of the effect of SSB taxes on youth consumption, and contribute to the limited evidence base on the impact of SSB taxes on weight, or in non-Western countries.
\end{abstract}

John Cawley

2312 MVR Hall

Department of Policy Analysis and Management and Department of Economics

Cornell University

Ithaca, NY 14853

and NBER

JHC38@cornell.edu

Michael R. Daly

Cornell University

mrd257@cornell.edu
Rebecca Thornton

University of Illinois

214 David Kinley Hall

1407 W. Gregory

Urbana, IL

61801

rebeccat@illinois.edu 


\section{Introduction}

In response to the rising prevalence of obesity worldwide, there are increasing efforts to implement fiscal policies to promote healthy diets and prevent non-communicable disease (Teng et al. 2019, World Bank, 2020; WHO, 2015). An important trend is the taxation of sugar-sweetened beverages (SSBs), a category that includes sodas, colas, sports drinks, energy drinks, and sweetened juice drinks. Taxes on SSBs have been adopted by numerous countries worldwide, including Barbados, Chile, Finland, France, India, Ireland, Mexico, Morocco, Peru, the Philippines, Saudi Arabia, South Africa, the United Kingdom, as well as several Pacific island nations (Thow et al. 2018; World Bank 2020; Teng et al. 2019; Alvarado et al., 2019). ${ }^{2}$ At a subnational level, taxes have also been introduced in several U.S. cities (including Philadelphia, San Francisco, Oakland, Boulder, and Seattle) and Catalonia, Spain. Economists view such taxes as a way to internalize the external costs of obesity and diabetes (to which SSBs are seen to contribute) and address the "internal costs" of excessive consumption due to factors such as limited selfcontrol and time-inconsistent preferences (see, e.g., Allcott, Lockwood, and Taubinsky, 2019; Teng et al. 2019; World Bank, 2020). Based on these considerations, the World Health Organization recommends that nations tax sugar-sweetened beverages (WHO, 2015). Many of the taxes on SSBs have been implemented in the past decade, and thus there is only incomplete information about their effects.

This paper contributes to the evidence on SSB taxes in four important ways. First, we provide information about the impact of such taxes on the consumption of SSBs. In contrast, most research on SSB taxes has studied the impact on retail prices (e.g. estimated the pass-through of

\footnotetext{
${ }^{2}$ See World Bank (2020) for a world map of where taxes on SSBs have been adopted.
} 
the tax) or the impact on sales/purchases. ${ }^{3}$ The difference between studying sales/purchases and consumption is that it is not possible to tell from sales/purchase data (such as retail scanner data or home scan data) who consumes the products, or whether they are consumed at all. Moreover, consumption may respond less than local sales if consumers engage in cross-border shopping (i.e. switch to purchasing their SSBs in a nearby untaxed jurisdiction), something quite feasible for U.S. city-level taxes (see, e.g., Cawley, Frisvold, Hill, and Jones, 2019; 2020; Allcott et al., 2019; Powell, Leider, and Léger, 2020). This paper contributes to the literature on the impact of SSB taxes on consumption, which studies the taxes in Mexico (Sanchez-Romero et al., 2020), Hungary (WHO and National Institute for Food and Nutrition Science, 2015), Barcelona (Royo-Bordonada et al., 2019), and the U.S. cities of Berkeley (Falbe et al., 2016; Silver et al., 2017; Lee et al., 2019), Philadelphia (Cawley, Frisvold, Hill, and Jones, 2019; Zhong et al., 2018), and Oakland (Cawley, Frisvold, Hill, and Jones, 2020).

Second, we provide information about the impact of such taxes on body mass index (BMI). ${ }^{4}$ There is virtually no direct evidence on how the recent, large SSB taxes affect weight, BMI, or obesity; existing evidence comes from simulation studies (see World Bank, 2020, sections 3.2.4 and 3.3). ${ }^{5}$

Third, we contribute to the literature by studying how youth respond to SSB taxes. Much of the evidence regarding the effect of SSB taxes on consumption concerns adults. Building the evidence regarding youth is important because youth may respond differently than adults to SSB

\footnotetext{
${ }^{3}$ See Cawley, Frisvold, Jones, and Lensing (2021) for a review of the estimated pass-through of city-level SSB taxes in the U.S. and Cawley, Thow, Wen, and Frisvold (2019) for a review of the impacts of SSB taxes on prices, purchases, sales, and consumption.

${ }^{4}$ Body mass index (BMI) is calculated as weight in kilograms divided by height in meters squared. See Burkhauser and Cawley (2008) for a discussion of the strengths and weaknesses of BMI as a measure of fatness.

${ }^{5}$ Prior to the recent substantial excise taxes on SSBs, there existed variation across U.S. states in the sales tax on SSBs, or modest excise taxes on SSBs, which were exploited to estimate the effect of SSB taxes on BMI by Fletcher, Frisvold, and Tefft (2010a, 2010b, 2010c).
} 
taxes; see, e.g. Dubois, Griffith, and O’Connell (2020). Our paper contributes to the literature which has studied the impact on youth of the SSB taxes in Philadelphia (Cawley, Frisvold, Hill, and Jones, 2019) and Oakland (Cawley, Frisvold, Hill, and Jones, 2020); in both of these papers there was no detectable impact of the tax on consumption of SSBs among youths overall, but there was evidence of a decrease in consumption in Philadelphia among youths who were the largest baseline consumers (Cawley, Frisvold, Hill, and Jones, 2019).

Fourth, we contribute to the literature by studying the impact of an SSB tax in a nonWestern country. Most of the evidence regarding the effect of SSB taxes comes from the Americas (e.g. the United States, Mexico, and Chile) or Europe (e.g. Denmark, France, Hungary, Spain, and the U.K.); see the review in World Bank (2020). By studying the impact of the tax in Mauritius, we contribute to a literature that includes studies of the impacts of the SSB taxes in India, Saudi Arabia, and South Africa (Nakhimovsky et al. 2016; World Bank, 2020). In general, data from non-Western nations is under-represented in published research in health economics (Hirvonen, 2020) and the discipline of economics as a whole (Das et al., 2013).

To our knowledge, this paper is unique in that it is the only one to estimate how an SSB tax affects the consumption of SSBs and BMI among youth in a non-Western country. Using individual-level survey data of youth from the World Health Organization's Global School-Based Student Health Survey (GSHS), we estimate difference-in-difference models that compare the change in outcomes in Mauritius, which imposed a tax on SSBs in 2013, to those in Maldives, which did not implement such a tax. We cannot reject the null hypothesis of no effect of the SSB tax on either SSB consumption or BMI for the full sample of youth, but when we estimate models separately by sex, we find evidence that the tax significantly reduced the probability that boys consume SSBs. 


\section{Methods}

\subsection{Settings - Mauritius and Maldives}

Both our treated country of Mauritius and the comparison country of Maldives are island nations located in the Indian Ocean. Both countries became independent from the United Kingdom in the 1960s and have a republican form of government. The population of Mauritius is 1.39 million, whereas that of Maldives is 391,000 (CIA 2021a, CIA 2021b). Mauritius was recently classified by the World Bank has a high-income country, having until then been classified as upper middle-income, whereas Maldives is still classified as upper middle-income. Both countries’ economies are heavily reliant on tourism. Real GDP per capita is \$22,870 in Mauritius and \$19,531 in Maldives (CIA 2021a, CIA 2021b). Mauritius is majority Hindu with a substantial Muslim minority while Maldives is Islamic (CIA 2021a, CIA 2021b). On its Human Development Index, which ranges from 0 to 1 and is a summary measure of health, education, and financial well-being, the United Nations rates Mauritius as 0.804 (very high human development) and Maldives as 0.74 (high human development); see United Nations (2020).

Mean BMI is similar in the two countries; for adult men it is 24.8 in Mauritius and 24.0 in Maldives, while for adult women it is 26.0 in Mauritius and 25.4 in Maldives (NCD Risk Factor Collaboration, 2016). We show later, in the empirical results section, that baseline SSB consumption is very similar in the two countries. Overall, the many similarities between these two countries suggest that Maldives is a suitable and appropriate comparison country for Mauritius in this context.

We estimate the impact of the excise tax on SSBs that was imposed in Mauritius on January 1, 2013. The tax, which applies to both locally manufactured and imported drinks, was equal to 3 
Mauritian rupees (roughly 8 US cents) per 100g of sugar content. In October 2016 that tax rate was doubled from 3 to 6 rupees (roughly 16 US cents) per 100g of sugar content (World Bank, 2020; Mauritius Revenue Authority, 2021). The tax on a two-liter bottle of Coke (which has 220 g sugar) was 6.6 rupees from 2013-October 2016, and 13.2 rupees since October 2016. Given the suggested retail price for a two-liter bottle of Coke of 63 rupees (Phoenix Beverages Limited, 2021), the tax was equal to roughly $10.5 \%$ from 2013 -October 2016 , and roughly $21 \%$ since October 2016. ${ }^{6}$

The design of the tax is interesting, as Mauritius is one of only a small number of countries (Chile, Cook Islands, France, Ireland, South Africa, Sri Lanka, and the United Kingdom) to tax SSBs on the basis of their sugar content (World Bank, 2020; Saxena et al., 2019; Teng et al. 2021; Nakamura et al., 2018). In contrast, most countries with SSB taxes levy a flat amount per ounce on sweetened caloric drinks.

In some studies, policy endogeneity is an issue; that is, there is concern that the treatment country may differ in important ways from the comparison country precisely because the treatment country but not the comparison country chose to enact the policy. Such concerns are somewhat alleviated in this case by the fact that our comparison country - Maldives - also implemented a fiscal policy to raise the price of SSBs, but they did so in 2017, after the time period examined in this study. ${ }^{7}$

\subsection{Data}

\footnotetext{
${ }^{6}$ For comparison, the one-cent-per-ounce SSB taxes in San Francisco and three other cities in California represent slightly more than $10 \%$ of the pre-tax price of a 20 -ounce SSB.

${ }^{7}$ Specifically, Maldives implemented an import tariff of 33.64 MVR/liter on energy drinks and 4.60 MVR/liter on soft drinks in March, 2017; see WHO (2017).
} 
We use data from the World Health Organization’s Global School-Based Student Health Survey (GSHS), an international surveillance effort to help countries assess behavioral risk factors among youths aged 12 to 17 years. The questions contained in the GSHS, and its years of administration, vary across countries. We use two waves of data for each country: for Mauritius there exist data for 2011 and 2017, and for Maldives there exist data for 2009 and 2014. Both Mauritius and Maldives asked youth about their consumption of sugar-sweetened beverages. The specific question is: "During the past 30 days, how many times per day did you usually drink carbonated soft drinks, such as [COUNTRY SPECIFIC EXAMPLES]? (Do not include diet soft drinks.)” The six possible answers are: a) I did not drink carbonated soft drinks during the past 30 days; b) Less than 1 time per day; c) 1 time per day; d) 2 times per day; e) 3 times per day; f) 4 times per day; g) 5 or more times per day. ${ }^{8}$

\subsection{Empirical Strategy}

We estimate the following difference-in-differences model:

$$
Y_{i c t}=\alpha+\beta_{1} T R E A T+\beta_{2} P O S T+\beta_{3} T R E A T * P O S T+\beta_{4} X+\varepsilon_{i c}
$$

Where $Y_{i c}$ is the outcome for individual $i$ in country $c$ in time $t$. TREAT equals one for individuals living in Mauritius, and 0 for those living in Maldives. POST equals one for the post-tax wave, and zero for the pre-tax wave. $X$ is a vector of control variables: an indicator variable for sex and a set of indicators for age in years. ${ }^{9}$

Our primary outcome variable $Y$ is the number of carbonated drinks consumed per day in the past 30 days. This is reported categorically: 0 , less than 1, 1, 2, 3, 4, and 5 or more. Less than

\footnotetext{
${ }^{8}$ See https://www.who.int/ncds/surveillance/gshs/GSHS_Core_Modules_2013_English.pdf

${ }^{9}$ Indicators for age include each year 12 through 17, plus one for 18 and older. The excluded reference category is 11 or younger. For both countries, the pre-tax waves had a top code of " 16 years and older" and the post-tax waves had a top code of "18 and older."
} 
1 per day is coded as 0.5 , and 5 or more is coded as $6 .{ }^{10}$ Other outcomes we examine include: the extensive margin of consuming SSBs (a binary variable for consuming a nonzero amount per day), an indicator variable for whether the respondent reports drinking the highest category of 5 or more SSBs per day, and body mass index (BMI), which is calculated using self-reported weight and height.

Our parameter of interest is the difference-in-difference estimator $\beta_{3}$, which measures the change in the outcome from before to after the tax in the treated country of Mauritius relative to the comparison country of Maldives. Given that the tax raises the price of SSBs, we hypothesize that $\beta_{3}<0$; that is, that the tax will reduce consumption of SSBs and may result in a decrease in BMI.

Observations are weighted using GSHS sample weights, and standard errors account for the complex survey design of GSHS. We initially estimate a pooled regression with both boys and girls, and then estimate the model separately by gender.

\section{Empirical Results}

\section{1 Summary Statistics}

Table 1 presents summary statistics for the samples from Mauritius and Maldives. Respondents in the two countries are quite similar prior to the tax. For example, the average number of drinks per day prior to the tax is 0.94 in Mauritius and 0.95 in Maldives. Average BMI prior to the tax is 19.65 in Mauritius compared to 19.03 in Maldives. Both samples are just over 54\% female, and Maldives sample is slightly older (14.9 years compared to 13.9 for Mauritius). Our pooled regression sample (both countries, both time periods) contains 11,627 observations for

\footnotetext{
10 The proportion of sample respondents in each category of SSB drink consumption per day is as follows: zero (21.56\%), less than 1 (41.78\%), one (18.51\%), two (8.9\%), three (3.99\%), four $(1.46 \%)$, and five or more (3.81\%).
} 
SSB consumption and 9,330 observations for BMI (the sample is smaller for BMI than for SSB consumption because of non-response to the questions about weight and height).

\subsection{Difference-in-Difference Results}

Table 2 presents results from our difference-in-differences (DiD) models. The top row contains estimates of the difference-in-differences estimator $\left(\beta_{3}\right.$, the coefficient on TREAT*POST). The columns of Table 2 present results from DiD regressions for each outcome: SSBs per day, whether consume any SSBs, consuming 5 or more SSBs per day, and BMI.

Overall, our estimates of the effect of the tax among the entire sample of youth are not statistically significant: we find that the tax increases consumption of SSBs by 0.109 drinks per day (or 11.7\%), lowers the likelihood of consuming any SSBs by 2.4 percentage points (3.0\%), and increases the probability of drinking 5 or more SSBs per day by 1.0 percentage points (41.7\%). Finally, we estimate that the tax lowered BMI by 0.084 units (0.43\%); each of these estimates are not statistically significant at traditional levels.

Boys and girls may differ in their levels of SSB consumption and in their price elasticities of demand. Table 3 shows that, in the pre-tax period, in both Mauritius and Maldives, boys are significantly more likely than girls to report drinking SSBs, and boys report significantly higher daily consumption of SSBs. ${ }^{11}$ In order to allow for the possibility of heterogeneous treatment effects, we estimate the difference-in-difference model separately by sex. Table 4 reports results for girls; once again, none of the difference-in-differences estimates are statistically significant, and the three estimates concerning SSB consumption are of the opposite sign expected (positive

\footnotetext{
${ }^{11}$ For comparison, SSB consumption is also more common among boys than girls in the U.S. Among youths aged 219 years in the U.S., $70 \%$ of boys, versus $60 \%$ of girls, consume sugary drinks on a given day. The average daily calorie intake from sugary drinks among U.S. teens aged 12-19 was 273 for boys and 171 for girls (Ogden et al., 2011).
} 
rather than negative). Table 5 reports results for boys; for them the tax lowers the probability of consuming any SSBs by 9.4 percentage points (11\%), which is statistically significant at the $1 \%$ level. There is no detectable impact of the SSB tax on the other three outcomes for boys.

\section{Discussion}

We estimate the effect of the tax on SSBs that was implemented in Mauritius in 2013. Comparing changes over time in Mauritius to those in the comparison country of Maldives, we are unable to reject the null hypothesis of no effect of the tax on SSB consumption or BMI for our pooled sample of boys and girls. When we estimate models separately by sex, however, we estimate that the tax reduced the probability that boys consume any SSBs by 9.4 percentage points or $11 \%$, which is statistically significant at the $1 \%$ level.

This paper makes four important contributions to the literature on SSB taxes. First, we add to the evidence base regarding how consumption of SSBs responds to an SSB tax. Much of the previous literature examines the impact on sales, purchases, or prices. Second, we estimate the impact of an SSB tax on BMI. In models estimated for the full sample of youths, as well as for boys and girls separately, we fail reject the null hypothesis of no effect. These represent the first estimates of the impact of SSB taxes on BMI for the new, large SSB taxes. ${ }^{12}$ Third, this paper adds to the relatively small literature on how youths in particular respond to SSB taxes. A strength of this paper is that its sample size (over 11,000) is the largest of any study of how SSB taxes affect youth consumption. Fourth, we provide evidence on the effects of such taxes in a nation outside of the Western hemisphere. In contrast, the vast majority of existing evidence comes from Europe (e.g. Denmark, France, Hungary, Spain, and the U.K.) or the Americas (e.g. the U.S., Mexico, and

\footnotetext{
12 Fletcher, Frisvold, and Tefft (2010a, 2010b, 2010c) estimated the impact on BMI of sales taxes, or small excise taxes, on SSBs in the U.S.
} 
Chile). To our knowledge, this paper is the only study of how the consumption of SSBs by youths responds to an SSB tax in a non-Western nation.

When we estimate our models for boys and girls pooled, we are unable to reject the null hypothesis that SSB taxes have no effect on whether youths consume SSBs, the frequency with which they consume them, or BMI. This is consistent with the few other studies of youth consumption, which examined data from Philadelphia and Oakland (Cawley, Frisvold, Hill, and Jones, 2019, 2020) and also failed to reject the null hypothesis of no effect. However, there was evidence in Philadelphia that the youth with the largest pre-tax consumption of added sugars through SSBs experienced a significant decline in consumption of added sugars through SSBs after the tax (Cawley, Frisvold, Hill, and Jones, 2019). In the subgroup analyses of this paper, we find that the tax significantly reduced the probability that boys consume any SSBs. The results of this paper, combined with the aforementioned ones from Philadelphia, represent the first evidence that SSB taxes reduce SSB consumption for certain groups of youths.

This paper has the following limitations. Although we have a pooled sample of over 11,000 observations, we have limited statistical power to detect smaller effect sizes, particularly when we estimate models separately by sex. The $95 \%$ confidence intervals contain meaningful effect sizes; for example, the estimated effect of the tax on SSBs per day for the pooled sample is a nonsignificant increase of 0.109 drinks per day (or 11.7\%), although that is the opposite sign than predicted. For each country, we only have one time period prior to the tax and one after the tax, which prevents us from assessing the identifying assumption of parallel trends (e.g. it is impossible to examine trends prior to the tax). Our data are repeated cross-sections rather than longitudinal, and thus we cannot observe changes over time for individual youth. Our measure of BMI is calculated using self-reported, rather than measured, weight and height; as a result, it contains 
some degree of reporting error. We have only two geographic clusters (nations) in our sample, so we cannot cluster by geography. This is a common limitation in this literature, however (e.g. see Cawley, Frisvold, Hill, and Jones, 2019, 2020) and some studies of national taxes have only one geographic cluster (i.e. no data for a comparison country). Finally, this is an examination of a single nation's SSB tax, and results may not generalize to other countries. However, it is a strength that we add to the evidence base not only data from a new country whose tax had not been previously studied, but also evidence from a non-Western nation, which is arguably underrepresented in health economics research (Hirvonen, 2020) and economics research more generally (Das et al., 2013). Despite its limitations, this study provides important new information on the effects of SSB taxes on youth. An important direction for future research is to study the effects of the many other SSB taxes that have recently been implemented across the globe, which would further add to the evidence base. 


\section{Works Cited}

Allcott, H., Lockwood, B. B., \& Taubinsky, D. (2019). Should we tax soda? An overview of theory and evidence. Journal of Economic Perspectives, 33(3), 202-227. https://doi.org/10.1257/jep.33.3.202

Alvarado, M., Unwin, N., Sharp, S. J., Hambleton, I., Murphy, M. M., Samuels, T. A., ... Adams, J. (2019). Assessing the impact of the Barbados sugar-sweetened beverage tax on beverage sales: An observational study. International Journal of Behavioral Nutrition and Physical Activity, 16(1), 1-11. https://doi.org/10.1186/s12966-019-0776-7

Burkhauser, R. V., \& Cawley, J. (2008). Beyond BMI: The value of more accurate measures of fatness and obesity in social science research. Journal of Health Economics, 27(2), 519-529. https://doi.org/10.1016/j.jhealeco.2007.05.005

Cawley, J., Frisvold, D., Hill, A., \& Jones, D. (2019). The impact of the Philadelphia beverage tax on purchases and consumption by adults and children. Journal of Health Economics, 67, 102225. https://doi.org/10.1016/j.jhealeco.2019.102225

Cawley, J., Frisvold, D., Hill, A., \& Jones, D. (2020). Oakland's sugar-sweetened beverage tax: Impacts on prices, purchases and consumption by adults and children. Economics and Human Biology, 37, 100865. https://doi.org/10.1016/j.ehb.2020.100865

Cawley, J., Frisvold, D., Jones, D., \& Lensing, C. (2021). The pass-through of a tax on sugarsweetened beverages in Boulder, Colorado. American Journal of Agricultural Economics, 103(3), 987-1005. https://doi.org/10.1111/ajae.12191

Cawley, J., Thow, A. M., Wen, K., \& Frisvold, D. (2019). The economics of taxes on sugarsweetened beverages: A review of the effects on prices, sales, cross-border shopping, and consumption. Annual Review of Nutrition, 39, 317-338. https://doi.org/10.1146/annurevnutr-082018-124603

Central Intelligence Agency. (2021a). Maldives. Retrieved from The World Factbook website: https://www.cia.gov/the-world-factbook/countries/maldives/

Central Intelligence Agency. (2021b). Mauritius. Retrieved from The World Factbook website: https://www.cia.gov/the-world-factbook/countries/mauritius/

Das, J., Do, Q.-T., Shaines, K., \& Srikant, S. (2013). US and them: The geography of academic research. Journal of Development Economics, 105, 112-130. https://doi.org/10.1016/j.jdeveco.2013.07.010

Dubois, P., Griffith, R., \& O’Connell, M. (2020). How well targeted are soda taxes? American Economic Review, 110(11), 3661-3704. https://doi.org/10.1257/AER.20171898

Falbe, J., Thompson, H. R., Becker, C. M., Rojas, N., McCulloch, C. E., \& Madsen, K. A. (2016). Impact of the Berkeley excise tax on sugar-sweetened beverage consumption. American Journal of Public Health, 106(10), 1865-1871. https://doi.org/10.2105/AJPH.2016.303362

Fletcher, J. M., Frisvold, D. E., \& Tefft, N. (2010a). The effects of soft drink taxes on child and adolescent consumption and weight outcomes. Journal of Public Economics, 94(11-12), 967-974. https://doi.org/10.1016/j.jpubeco.2010.09.005

Fletcher, J. M., Frisvold, D., \& Tefft, N. (2010b). Can soft drink taxes reduce population weight? Contemporary Economic Policy, 28(1), 23-35. https://doi.org/10.1111/j.14657287.2009.00182.x 
Fletcher, J. M., Frisvold, D., \& Tefft, N. (2010c). Taxing soft drinks and restricting access to vending machines to curb child obesity. Health Affairs, 29(5), 1059-1066.

https://doi.org/10.1377/hlthaff.2009.0725

Hirvonen, K. (2020). This is US: Geography of evidence in top health economics Journals. Health Economics Letter. 29(10): 1316-1323.

Lee, M. M., Falbe, J., Schillinger, D., Basu, S., McCulloch, C. E., \& Madsen, K. A. (2019). Sugar-sweetened beverage consumption 3 years after the Berkeley, California, sugarsweetened beverage tax. American Journal of Public Health, 109(4), 637-639. https://doi.org/10.2105/AJPH.2019.304971

Mauritius Revenue Authority. (2021). Excise tax on sugar content of sugar sweetened nonalcoholic beverages. Retrieved November 6, 2021, from https://www.mra.mu/index.php/customs1/more-topics/excise-tax-on-sugar-content-of-sugarsweetened-non-alcoholic-beverages

NCD Risk Factor Collaboration (2016). Trends in adult body-mass index in 200 countries from 1975 to 2014: A pooled analysis of 1698 population-based measurement studies with 19.2 million participants. Lancet, 387, 1377-1396. https://doi.org/10.1016/S01406736(16)30054-X

Nakamura, R., Mirelman, A. J., Cuadrado, C., Silva-Illanes, N., Dunstan, J., \& Suhrcke, M. (2018). Evaluating the 2014 sugar-sweetened beverage tax in Chile: An observational study in urban areas. PLoS Medicine, 15(7), 1-22. https://doi.org/10.1371/journal.pmed.1002596

Nakhimovsky, S. S., Feigl, A. B., Avila, C., O’Sullivan, G., MacGregor-Skinner, E., \& Spranca, M. (2016). Taxes on sugar-sweetened beverages to reduce overweight and obesity in middle-income countries: A systematic review. PLoS ONE, 11(9), 1-22. https://doi.org/10.1371/journal.pone.0163358

Ogden, C. L., Kit, B. K., Carroll, M. D., \& Park, S. (2011). Consumption of sugar drinks in the United States, 2005-2008. Retrieved from NCHS data brief website: https://www.cdc.gov/nchs/data/databriefs/db71.pdf

Powell, L. M., Leider, J., \& Léger, P. T. (2020). The impact of a sweetened beverage tax on beverage volume sold in Cook county, Illinois, and its border area. Annals of Internal Medicine, 172(6), 390-397. https://doi.org/10.7326/M19-2961

Phoenix Beverages Limited. (2021). Wholesale Price List. Retrieved from https://phoenixbev.mu/media/pdf/media_pdf_1592889039.pdf

Royo-Bordonada, M. Á., Fernández-Escobar, C., Simón, L., Sanz-Barbero, B., \& Padilla, J. (2019). Impact of an excise tax on the consumption of sugar-sweetened beverages in young people living in poorer neighbourhoods of Catalonia, Spain: A difference in differences study. BMC Public Health, 19(1), 1-11. https://doi.org/10.1186/s12889-019-7908-5

Sánchez-Romero, L. M., Canto-Osorio, F., González-Morales, R., Colchero, M. A., Ng, S. W., Ramírez-Palacios, P., ... Barrientos-Gutiérrez, T. (2020). Association between tax on sugar sweetened beverages and soft drink consumption in adults in Mexico: Open cohort longitudinal analysis of Health Workers Cohort Study. The BMJ, 369. https://doi.org/10.1136/bmj.m1311

Saxena, A., Stacey, N., Puech, P. D. R., Mudara, C., Hofman, K., \& Verguet, S. (2019). The distributional impact of taxing sugar-sweetened beverages: Findings from an extended costeffectiveness analysis in South Africa. BMJ Global Health, 4(4).

https://doi.org/10.1136/bmjgh-2018-001317 
Silver, L. D., Ng, S. W., Ryan-Ibarra, S., Taillie, L. S., Induni, M., Miles, D. R., ... Popkin, B. M. (2017). Changes in prices, sales, consumer spending, and beverage consumption one year after a tax on sugar-sweetened beverages in Berkeley, California, US: A before-andafter study. PLoS Medicine, 14(4), 1-19. https://doi.org/10.1371/journal.pmed.1002283

Teng, A. M., Genç, M., Herman, J., Signal, L., Areai, D., \& Wilson, N. (2021). Impact of sugarsweetened beverage taxes on price, import and sale volumes in an island: Interrupted time series analysis. Public Health Nutrition, 24(7), 1828-1835. https://doi.org/10.1017/S1368980021000185

Teng, AM, Jones, AC, Mizdrak, A, Signal, L, Genç, M, Wilson, N. (2019) Impact of sugarsweetened beverage taxes on purchases and dietary intake: Systematic review and metaanalysis. Obesity Reviews, 20, 1187- 1204. https://doi.org/10.1111/obr.12868

Thow, A. M., Downs, S. M., Mayes, C., Trevena, H., Waqanivalu, T., \& Cawley, J. (2018). Fiscal policy to improve diets and prevent noncommunicable diseases: From recommendations to action. Bulletin of the World Health Organization, 96(3), 201-210. https://doi.org/10.1017/S1368980021000185

United Nations. (2020). Human Development Report 2020. Retrieved from http://hdr.undp.org/sites/default/files/hdr2020.pdf

WHO. (2015). Fiscal policies for diet and the prevention of noncommunicable diseases. WHO Regional Office for Europe, (May), 36. Retrieved from http://www.who.int/dietphysicalactivity/publications/fiscal-policies-diet-prevention/en/

WHO. (2017). Report on fiscal policies to reduce consumption of sugar-sweetened beverages and other regulatory measures to promote healthy diets in the republic of Maldives. WHO Regional Office for Europe. Retrieved from http://www.searo.who.int/maldives/documents/report-on-fiscal-policies-reduceconsumption-sugar.pdf?ua $=1$

WHO and National Institute for Food and Nutrition Science Directorate General. (2015). Assessment of the impact of a public health product tax. Retrieved June 11, 2021, from Final Report website: https://www.euro.who.int/_data/assets/pdf_file/0008/332882/assessment-impact-PH-taxreport.pdf

World Bank. (2020). Taxes on sugar-sweetened beverages: summary of international evidence and experiences. Retrieved from https://openknowledge.worldbank.org/handle/10986/33969

Zhong, Y., Auchincloss, A. H., Lee, B. K., \& Kanter, G. P. (2018). The short-term impacts of the Philadelphia beverage tax on beverage consumption. American Journal of Preventive Medicine, 55(1), 26-34. https://doi.org/10.1016/j.amepre.2018.02.017 
Table 1: Summary Statistics

\begin{tabular}{|c|c|c|c|c|c|c|}
\hline \multirow{3}{*}{ Panel A: Pre-peric } & \multicolumn{3}{|c|}{ Mauritius } & \multicolumn{3}{|c|}{ Maldives } \\
\hline & Mean & s.d. & $\mathrm{N}$ & Mean & s.d. & $\mathrm{N}$ \\
\hline & & & & & & \\
\hline Drinks per day & 0.935 & 1.137 & 2147 & 0.952 & 1.337 & 3176 \\
\hline Any drinks & 0.790 & 0.407 & 2147 & 0.766 & 0.424 & 3176 \\
\hline 5 or more drinks & 0.024 & 0.152 & 2147 & 0.045 & 0.208 & 3176 \\
\hline $\mathrm{BMI}$ & 19.651 & 4.237 & 2083 & 19.032 & 4.107 & 1768 \\
\hline Female & 0.542 & 0.498 & 2162 & 0.547 & 0.498 & 3205 \\
\hline Age in years & 13.907 & 1.037 & 2161 & 14.903 & 1.045 & 3138 \\
\hline \multicolumn{7}{|c|}{ Panel B: Post-period } \\
\hline Drinks per day & 1.058 & 1.280 & 2982 & 0.956 & 1.316 & 3397 \\
\hline Any drinks & 0.812 & 0.391 & 2982 & 0.788 & 0.409 & 3397 \\
\hline 5 or more drinks & 0.034 & 0.180 & 2982 & 0.044 & 0.205 & 3397 \\
\hline $\mathrm{BMI}$ & 20.719 & 5.031 & 2931 & 19.864 & 4.241 & 2548 \\
\hline Female & 0.528 & 0.499 & 2998 & 0.576 & 0.494 & 3436 \\
\hline Age in years & 14.873 & 1.395 & 2997 & 15.521 & 1.471 & 3429 \\
\hline
\end{tabular}


Table 2: Difference-in-Difference results

\begin{tabular}{lcccc}
\hline Dependent Variable: & SSBs per day & Any SSBs & 5 or more SSBs & BMI \\
\hline Post*Treat & 0.109 & -0.024 & 0.010 & 0.084 \\
Post period & $(0.087)$ & $(0.023)$ & $(0.011)$ & $(0.252)$ \\
& 0.016 & 0.039 & -0.001 & 0.511 \\
Treatment indicator & $(0.056)$ & $(0.017)^{* *}$ & $(0.008)$ & $(0.207)^{* *}$ \\
& -0.014 & 0.059 & -0.022 & 1.256 \\
Female & $(0.062)$ & $(0.019)^{* * *}$ & $(0.008)$ & $(0.193)^{* * *}$ \\
& -0.123 & -0.060 & -0.009 & 0.111 \\
Age is 12 yrs & $(0.059)^{* *}$ & $(0.012)^{* * *}$ & $(0.006)$ & $(0.141)$ \\
& -0.945 & -0.056 & -0.149 & -2.394 \\
Age is 13 yrs & $(0.387)^{* *}$ & $(0.076)$ & $(0.067)$ & $(1.752)$ \\
Age is 14 yrs & -0.766 & -0.033 & -0.136 & -1.827 \\
Age is 15 yrs & $(0.385)^{* *}$ & $(0.075)$ & $(0.067)$ & $(1.803)$ \\
& -0.724 & -0.028 & -0.140 & -1.417 \\
Age is 16 yrs & $(0.381)^{*}$ & $(0.076)$ & $(0.067)$ & $(1.795)$ \\
Age is 17 yrs & -0.699 & 0.008 & -0.131 & -0.989 \\
Age is 18 yrs or older & $(0.381)^{*}$ & $(0.077)$ & $(0.067)$ & $(1.782)$ \\
constant & -0.775 & -0.003 & -0.130 & -0.346 \\
N squared & $(0.378)^{* *}$ & $(0.076)$ & $(0.066)$ & $(1.788)$ \\
Mean of dep variable in & -0.846 & 0.011 & -0.148 & -0.066 \\
\hline \hline
\end{tabular}

Notes: Results incorporate sample weights. Taylor linearized standard errors accounting for survey psu and stratum are reported in parentheses. Statistical significance is indicated by: ${ }^{*} 0.1,{ }^{* *} 0.05$, and ${ }^{* * *} 0.01$. Due to missing observations on BMI from a few classrooms there are a number of strtum with only one psu for this outcome, in this case the average of the variances from the stratum with multiple psu for each is used for each stratum with only 1 psu.\} 
Table 3: Average Outcomes by Sex

\begin{tabular}{|c|c|c|c|c|c|c|}
\hline \multirow[b]{2}{*}{ Panel A: Pre-period } & \multicolumn{3}{|c|}{ Mauritius } & \multicolumn{3}{|c|}{ Maldives } \\
\hline & $\begin{array}{c}\text { mean } \\
\text { (female) }\end{array}$ & $\begin{array}{c}\text { mean } \\
\text { (male) }\end{array}$ & difference & $\begin{array}{c}\text { mean } \\
\text { (female) }\end{array}$ & $\begin{array}{l}\text { mean } \\
\text { (male) }\end{array}$ & difference \\
\hline Drinks per day & 0.865 & 1.019 & $0.154^{* * *}$ & 0.841 & 1.086 & $0.245^{* * *}$ \\
\hline Any drinks & 0.735 & 0.857 & $0.122 * * *$ & 0.748 & 0.787 & $0.040 * * *$ \\
\hline 5 or more drinks & 0.021 & 0.028 & 0.007 & 0.029 & 0.065 & $0.035 * * *$ \\
\hline BMI & 19.758 & 19.522 & -0.236 & 18.738 & 19.381 & $0.643 * * *$ \\
\hline \multicolumn{7}{|l|}{ Panel B: Post-period } \\
\hline Drinks per day & 1.047 & 1.070 & 0.023 & 0.844 & 1.110 & $0.266 * * *$ \\
\hline Any drinks & 0.804 & 0.821 & 0.017 & 0.762 & 0.823 & $0.062 * * *$ \\
\hline 5 or more drinks & 0.035 & 0.032 & -0.003 & 0.031 & 0.062 & $0.031 * * *$ \\
\hline BMI & 20.876 & 0.542 & $-0.334^{*}$ & 19.735 & 20.045 & $0.310 *$ \\
\hline
\end{tabular}


Table 4: Difference-in-difference results for females in Mauritius and Maldives

\begin{tabular}{|c|c|c|c|c|}
\hline Dependent Variable: & SSBs per day & Any SSBs & 5 or more SSBs & $\mathrm{BMI}$ \\
\hline \multirow[t]{2}{*}{ Post*Treat } & 0.195 & 0.040 & 0.013 & -0.204 \\
\hline & $(0.128)$ & $(0.032)$ & $(0.014)$ & (0.339) \\
\hline \multirow[t]{2}{*}{ Post period } & 0.020 & 0.028 & 0.004 & 0.786 \\
\hline & $(0.066)$ & $(0.024)$ & $(0.008)$ & $(0.250)^{* * *}$ \\
\hline \multirow[t]{2}{*}{ Treatment indicator } & 0.039 & 0.011 & -0.005 & 1.704 \\
\hline & $(0.084)$ & $(0.024)$ & $(0.009)$ & $(0.246)^{* * *}$ \\
\hline \multirow[t]{2}{*}{ Age is 12 yrs } & -1.432 & -0.107 & -0.239 & 0.094 \\
\hline & $(0.638) * *$ & $(0.118)$ & $(0.103)$ & (1.418) \\
\hline \multirow[t]{2}{*}{ Age is 13 yrs } & -1.262 & -0.065 & -0.217 & 0.666 \\
\hline & $(0.629) * *$ & $(0.107)$ & $(0.104)$ & (1.433) \\
\hline \multirow[t]{2}{*}{ Age is 14 yrs } & -1.179 & -0.063 & -0.221 & 1.129 \\
\hline & $(0.628)^{*}$ & $(0.106)$ & $(0.103)$ & $(1.437)$ \\
\hline \multirow[t]{2}{*}{ Age is 15 yrs } & -1.180 & -0.052 & -0.211 & 1.377 \\
\hline & $(0.628)^{*}$ & $(0.106)$ & $(0.103)$ & $(1.418)$ \\
\hline \multirow[t]{2}{*}{ Age is 16 yrs } & -1.296 & -0.054 & -0.216 & 2.387 \\
\hline & $(0.622)^{* *}$ & $(0.107)$ & $(0.102)$ & $(1.445)$ \\
\hline \multirow[t]{2}{*}{ Age is 17 yrs } & -1.390 & -0.042 & -0.237 & 2.257 \\
\hline & $(0.624)^{* *}$ & $(0.111)$ & $(0.104)$ & $(1.453)$ \\
\hline \multirow[t]{2}{*}{ Age is 18 yrs } & -1.281 & -0.064 & -0.224 & 2.192 \\
\hline & $(0.642) * *$ & $(0.106)$ & $(0.103)$ & $(1.471)$ \\
\hline \multirow[t]{2}{*}{ constant } & 2.056 & 0.786 & 0.244 & 17.035 \\
\hline & $(0.648) * * *$ & $(0.108) * * *$ & $(0.106)^{* *}$ & $(1.461)^{* * *}$ \\
\hline $\mathrm{N}$ & 6406 & 6406 & 6406 & 5145 \\
\hline R squared & 0.013 & 0.008 & 0.007 & 0.039 \\
\hline $\begin{array}{l}\text { Mean of dep variable in } \\
\text { Mauritius before tax }\end{array}$ & 0.865 & 0.735 & 0.021 & 19.758 \\
\hline $\begin{array}{l}\text { Notes: Results incorpora } \\
\text { survey psu and stratum a } \\
* 0.1, * * 0.05 \text {, and } * * * 0.0 \\
\text { are a number of stratum } \\
\text { variances from the stratu }\end{array}$ & veights. Tayl & linearized st & dard errors acce & $\begin{array}{l}\text { Inting for } \\
\text { ated by: } \\
\text { ooms there } \\
\text { e of the } \\
\text { only } 1 \text { psu. }\end{array}$ \\
\hline
\end{tabular}


Table 5: Difference-in-difference results for males in Mauritius and Maldives

\begin{tabular}{|c|c|c|c|c|}
\hline Dependent Variable: & SSBs per day & Any SSBs & 5 or more SSBs & BMI \\
\hline \multirow[t]{2}{*}{ Post*Treat } & 0.013 & -0.094 & 0.008 & 0.453 \\
\hline & $(0.125)$ & $(0.028)^{* * *}$ & $(0.016)$ & $(0.354)$ \\
\hline \multirow[t]{2}{*}{ Post period } & 0.007 & 0.051 & -0.007 & 0.186 \\
\hline & $(0.078)$ & $(0.024)^{* *}$ & $(0.011)$ & $(0.293)$ \\
\hline \multirow[t]{2}{*}{ Treatment indicator } & -0.064 & 0.110 & -0.038 & 0.745 \\
\hline & $(0.100)$ & $(0.023) * * *$ & $(0.014)$ & $(0.259) * * *$ \\
\hline \multirow[t]{2}{*}{ Age is 12 yrs } & -0.545 & -0.008 & -0.074 & -3.785 \\
\hline & $(0.455)$ & $(0.081)$ & $(0.080)$ & $(2.104)^{*}$ \\
\hline \multirow[t]{2}{*}{ Age is 13 yrs } & -0.353 & -0.008 & -0.071 & -3.242 \\
\hline & $(0.442)$ & $(0.080)$ & $(0.078)$ & (2.163) \\
\hline \multirow[t]{2}{*}{ Age is 14 yrs } & -0.355 & 0.003 & -0.073 & -2.885 \\
\hline & $(0.444)$ & $(0.081)$ & $(0.079)$ & $(2.154)$ \\
\hline \multirow[t]{2}{*}{ Age is 15 yrs } & -0.307 & 0.060 & -0.066 & -2.265 \\
\hline & $(0.438)$ & $(0.079)$ & $(0.079)$ & $(2.172)$ \\
\hline \multirow[t]{2}{*}{ Age is 16 yrs } & -0.335 & 0.048 & -0.059 & -2.031 \\
\hline & $(0.445)$ & $(0.079)$ & $(0.081)$ & $(2.158)$ \\
\hline \multirow[t]{2}{*}{ Age is 17 yrs } & -0.387 & 0.061 & -0.075 & -1.313 \\
\hline & $(0.454)$ & $(0.083)$ & $(0.082)$ & $(2.146)$ \\
\hline \multirow[t]{2}{*}{ Age is $18 \mathrm{yrs}$} & -0.358 & 0.074 & -0.059 & -1.096 \\
\hline & $(0.468)$ & $(0.086)$ & $(0.082)$ & $(2.265)$ \\
\hline \multirow[t]{2}{*}{ constant } & 1.442 & 0.730 & 0.135 & 21.636 \\
\hline & $(0.443)^{* * *}$ & $(0.081)^{* * *}$ & $(0.078)^{*}$ & $(2.164) * * *$ \\
\hline $\mathrm{N}$ & 5221 & 5221 & 5221 & 4185 \\
\hline R squared & 0.002 & 0.012 & 0.009 & 0.033 \\
\hline $\begin{array}{l}\text { Mean of dep variable in Mauritius } \\
\text { before tax }\end{array}$ & 1.019 & 0.857 & 0.028 & 19.522 \\
\hline
\end{tabular}

Notes: Results incorporate sample weights. Taylor linearized standard errors accounting for survey psu and stratum are reported in parentheses. Statistical significance is indicated by: $* 0.1, * * 0.05$, and $* * * 0.01$. Due to missing observations on BMI from a few classrooms there are a number of stratum with only one psu for this outcome, in this case the average of the variances from the stratum with multiple psu for each is used for each stratum with only 1 psu. 